\title{
IGLESIA E INQUISICIÓN \\ EN LA ESPAÑA NORTEAFRICANA: \\ ORÁN Y MAZALQUIVIR A FINES DEL REINADO DE FELIPE II
}

POR

\author{
Beatriz Alonso Acero
}

Hispania Sacra

\section{RESUMEN}

La presencia de España en Orán y Mazalquivir desde comienzos del siglo XVI, remite a las tierras del otro lado del Estrecho la polémica sobre las relaciones entre Cristiandad, judaísmo e Islam. La recuperación de estos enclaves para el Cristianismo provoca la necesidad de reorganizar una Iglesia, tanto en lo que se refiere a la edificación de centros dedicados al culto, como a la implantación de un estamento eclesiástico que cumpla las importantes misiones que tiene encomendadas en estos presidios, que mantienen continuos contactos con Islam y judaísmo. La fragilidad de la frontera que separa a Cristiandad e Islam en este contexto tan específico, estimula la actuación del Santo Oficio de Murcia, el encargado de la jurisdicción inquisitorial de Orán y Mazalquivir, persiguiendo con especial fruición a los sospechosos de islamizar.

\begin{abstract}
The Spanish presence in Oran and Mazalquivir from the beginning of $16^{\text {th }}$ century sends to the lands on the other side of Strait of Gibraltar the polemic about the relations betweeen Christendom, judaism and Islam. The recovery of these enclaves for the Christianity, rouses the necessity of reorganizing the Christian church. This includes the construction of buildings dedicates to worship, and also the establishment of an ecclesiastic stait that observes the importants works he must make at these fortresses, which keep constants contacts with Islam and Judaism. The frailty of the frontier that keeps apart Christendom et Islarn in such specific context, rouses the action of Murcia Holy Office, the res-
\end{abstract}


ponsable of Oran and Mazalquivir inquisitorial jurisdiction, which pursues above all the suspects of being moslems.

La doble penetración portuguesa y española en las costas atlánticas y mediterráneas del continente vecino durante los siglos XV y XVI, abre paso a un nuevo período de irradiación del cristianismo en determinadas zonas del norte de África. Si bien esta religión ya había gozado de una importante difusión en los territorios norteafricanos previa a la gran expansión del Islam en la segunda mitad del siglo VII, lo cierto es que, en el período moderno, el cristianismo tiene una nueva oportunidad para defender su identidad en un territorio en el que el Islam es la confesión mayoritaria, aparte de la existencia de algunos núcleos judíos diseminados por estas latitudes magrebíes. En el caso del doble presidio de Mazalquivir y Orán', bajo dominio español desde 1505 y 1509 , respectivamente, y al configurarse ambas plazas como territorios de frontera entre Cristiandad e Islam, la Iglesia define su presencia y funciones en ellos a partir de las relaciones que establece con musulmanes y judíos, confesiones con las que entra en contacto incluso dentro de sus propias murallas². Será

1 Entendido el concepto de presidio como lugar en cl que se ejerce un dominio y se ofrece una protección, siguiendo la definición de F.F. Olesa Muñido, (F.F. OLESA MUŇıdo, La organización naval de los Estados mediterráneos y en especial de España durante los siglos XVI y XVI, Madrid, 1968, vol. II, p. 981), Orán y Mazalquivir, distantes entre sí apenas una legua, se convierten, desde sus respectivas conquistas, en plazas que comparten un único destino, además de un mismo gobierno y administración. Por esta razon, hay que referirse a ellos como "doble presidio".

2 Por lo que respecta a las relaciones con musulmanes, aunque en el doble presidio no se consiente su presencia estable, es fundamental la colaboración que se establece con aduares de moros de paz -siguiendo la terminología de la época-, algunos de los cuales se asientan en espacios muy próximos a las plazas cristianas, caso de los enclaves de Ifre y Canastel, y en ocasiones entran en el doble presidio para realizar sus transacciones comerciales con el gobernador y/o habitantes de las plazas. También habría que citar las relaciones de enfrentamiento -cabalgadas- con los moros de guerra, a partir de las cuales se consiguen los esclavos, algunos de los cuales son enviados a España, mientras que otros son adquiridos por vecinos del doble presidio. Caso específico es el de los mogataces, en su acepción de "moro que, bautizado o no, scrvía como espía, guía o auxiliar en las tropas españolas de ciertos presidios africanos" (F. MAílLo SALGADO, Breves notas sobre la historia y el significado de la palabra "almogataz": Studia Zamorensia, no 5, (1984), p. 480). Por lo que respecta a la presencia de judíos en Orán y Mazalquivir, recordemos que tras la inicial expulsión con motivo de la conquista de las plazas, Fernando el Católico, en 1512, otorga una cédula al gobemador, D. Diego Fernández de Córdoba, por la que se permite la estancia en las plazas de tres familias judías, la de Haben Semerro, Rubí Satorra y un tal Cansino, con quienes se ponen las bases de la presencia hebrea en este doble presidio. La evolución de la judería de Orán y las relaciones entre este núcleo y la mayoría cristiana estarán llenas de avatares, dando lugar a varios intentos de expulsión que culminan en 1669, cuando los judíos salen definitivanente de estas plazas. Con ello se pone fin a la cohabitación entre cristianos, musulmanes y judíos, la cual, desechada de los reinos peninsulares desde finales del siglo XV (por lo que respecta a los judíos) y desde comienzos del siglo XVI (para los musulmanes), se había prolongado en Orán durante un período de tiempo muy considerable. Estas

Aficiones y devociones en ef antiguo régimen

Hispania Sacra 50 (1998) 
precisamente este contacto el que active la actuación inquisitorial en estas plazas, a sabiendas de la amenaza que la coexistencia de estas tres culturas, aún continuada en Orán y Mazalquivir en las décadas postreras del reinado de Felipe II, podría llegar a ejercer sobre la estricta observancia de la fe cristiana.

\section{RESTABLECIMIENTO DEL CRISTIANISMO EN ORÁN Y MAZALQUIVIR}

La introducción del cristianismo en Mazalquivir y en Orán durante la Antigüedad se halla vinculada a la expansión romana en el norte de África. A partir de la localización de ambos territorios en la antigua Mauritania Cesariense romana, la recepción del cristianismo tiene lugar en los primeros siglos de nuestra era, estando ya plenamente constatada para finales del siglo $\mathrm{III}^{3}$. A pesar de sufrir los embates de las herejías arriana y donatita en las siguientes centurias, el cristianismo permanece presente en estas latitudes hasta la penetración del Islam, pasando Orán y Mazalquivir, desde comienzos del siglo VIII, a formar parte del vasto territorio de dominación musulmana en el norte de Africa. Tras el largo paréntesis marcado por la supremacía del Islam, la Iglesia vuelve a penetrar en Orán y Mazalquivir mediante la propia ocupación española de las plazas. En este sentido, es necesario tener en cuenta estas conquistas no sólo en su vertiente política y geoestratégica, como parte de un proyecto de recuperación de la España Transfetana, necesario para el control del Mediterráneo occidental, sino también como esencia integradora de un ideal religioso tendente a recuperar para la Cristiandad todos aquellos lugares que el

circunstancias tan especificas condicionan sobremanera el papel que la Iglesia y la Inquisición realizan en Orán y Mazalquivir durante el período moderno, tal y como pretendemos analizar en este estudio, referido a las últimas décadas del Quinientos.

3 Aunque tanto Orán como Mazalquivir, situadas en la actual Argelia occidental, adquicren identidad propia en el período moderno a partir de la dominación musulmana y posteriormente de la española, ambas poscen un pasado romano de innegable relevancia. Orán fue parte -la llamada Única Colonia- de ese vasto Imperio romano que alcanzó sus máximas fronteras en el transcurso del siglo I d.C., mientras que Mazalquivir, el Mers-El-Kebir musulmán, "es lo mismo que Puerto grande, como le nombraron los antiguos romanos y los mismos africanos cartagineses, juntando en el su fleteria para las conquistas de España, por no haber otro como él en toda la costa de Africa desde Xibraltar hasta Alexandria, ni tan a mano para España, y así le llamaban Porto Magno y Puerto Real". (D. SUÁREZ MONTAÑÉs, Historia del Maestre último que fue de Montesa y de su hermano D. Felipe de Borja, la manera cómo gobernó Orán y Mazalquivir ... siendo allí capitanes generales, Madrid, Sociedad Bibliófilos Españoles, 1889, parte I, cap. II, p. 26). Según G. Sánchez Doncel, "en lo que se refiere a la Mauritania Cesariense, hoy día dí́cesis de Orán, las huellas más lejanas de la existencia del cristianismo se remontan a principios del siglo IV, testificadas por una serie de epitafios hallados en Altava (Lamoricière) que datan del 302, de lo que se infiere que ya a finales del siglo III existirian en estas regiones una o más comunidades cristianas" (G. SÁNCHEZ DONCEL, Presencia de España en Orán (1509-1792), Toledo, 1991, pp. 444-445). 
Islam, en su expansión, le había arrebatado. Según esto, el propio cardenal Cisneros, como máximo inspirador y artífice de la conquista de Orán, abre camino a la entrada del cristianismo en estos territorios magrebíes que pasan a poder castellano.

En una primera línea de actuación, el restablecimiento de la Iglesia en Orán y Mazalquivir supone la construcción de diversos edificios dedicados al culto católico, así como la transformación de las anteriores mezquitas en iglesias cristianas. En Orán, la iglesia principal será la de Nuestra Señora de la Victoria, la "iglesia mayor" según la denomina la documentación de la época, que desempeñaba la función de parroquia. Se trata de una antigua mezquita consagrada al cristianismo por Cisneros tras la conquista de la plaza, y "de la que son feligreses o parroquianos todos los vecinos, moradores y las gentes de guerra" ". Muy próximos a ella se levantaban los conventos de las órdenes religiosas con representación en Orán: franciscanos y mercedarios - las dos desde el momento inmediatamente posterior a la conquista-, ésta última como orden redentora que desempeñaría una importante misión en una zona dominada por el Islam; en una época algo posterior, también llegarían los dominicos ${ }^{5}$. Cada uno de estos conventos tenía su propia iglesia. De igual forma, hay que citar para Orán la iglesia de San Bernardino, también antigua mezquita, al lado de la cual se edificó el hospital de la ciudad, del mismo nombre. Esta iglesia-hospital debe su patronímico al franciscano de Siena en cuya festividad -el 20 de mayo, dos días después de la conquista de la plaza- fue consagrado el doble edificio. Con el paso del tiempo, las construcciones de finalidad religiosa en Orán se irán completando con la aparición de diversas ermitas dentro y fuera de las murallas de la ciudad, entre las que cabe destacar las de San Miguel y Santiago, intramuros de Orán, y las de San Roque, San Sebastián y Nuestra Señora del Carmen, extramuros, todas ellas ya presentes en los planos urbanísticos del Orán de las primeras décadas del Seiscientos, si bien a lo largo de esta centuria aún se levantarán algunas ermitas más ${ }^{6}$. Por lo

4 F. JIMÉNEZ De GREGorIo, La visita a Orán del vicario Dr. Juan Luengo de Vieira en 16821683: Hispania, tomo XLVII, $\mathrm{n}^{\mathrm{D}} 167$ (1987), p. 932.

5 Según afirma R. Gutiérrez Cruz, la primera constancia que se tiene de la presencia de dominicos en Orán se puede fechar en 1515, cuando el receptor Fernando de Valera entrega a éstos 7.500 maravedís. (R. GUTIÉRREZ CRUZ, La presencia española en el norte de Áfica: el sistema de presidios en la época de los Reyes Católicos (1497-1516). Tesis Doctoral. Universidad de Málaga, 1994, p. 53. Para los planos, fachadas y alzados de algunos de estos edificios religiosos en Orán en la época modema, vid. M. de EPALZA, J.B. VILAR, Planos y mapas hispanicos de Argelia (siglos XVI-XVIII), Madrid, 1988, acudiendo a los planos $\mathrm{n}^{\circ} 223$ (Iglesia Mayor), 226 (Convento de San Francisco), 227, 228, 229 (Convento e Iglesia de Sto. Domingo).

6 Así, por ejemplo, la ermita de Nuestra Señora del Rosario, fundada por el marqués de San Román, gobernador de las plazas entre 1653 y 1660, y la del Santo Cristo de la Paciencia, fundada 
que respecta a la villa de Mazalquivir, en ella se halla enclavada la iglesiahospital de San Miguel, para el cuidado del cuerpo y alma de los enfermos de este enclave, "hospitalis pauperum sancti bernardi oranem ac sancti michaelis oppidi de maçarquibir oranem diocesis ecclesia"7. A finales del siglo XVI, el hospital no parece ya funcionar, perdurando tan sólo la iglesia, "en donde se da culto al Santísimo Sacramento"8.

En una segunda línea de actuación, el restablecimiento del cristianismo en estas latitudes norteafricanas a comienzos del siglo XVI, lleva consigo la necesidad de poner en marcha una adecuada organización eclesiástica en las plazas recién conquistadas. La idea de crear un obispado en Orán es la que más posibilidades mantiene en los primeros años tras la ocupación, pues supone otorgar mayor categoría a la Iglesia de estos territorios, algo muy importante dadas las especiales características que rodean a estos presidios norteafricanos. Sin embargo, tal proposición, "por bula pontifícia de León X en 1514 se anula erigiéndose solamente una iglesia colegial dependiente de la diócesis de Toledo bajo el patronato directo de los reyes de Castilla" 9 . Aunque este tema de la posible conversión de Orán en obispado volverá a adquirir protagonismo bien entrado el siglo XVII ${ }^{10}$, lo cierto es que en ningún momento llegará a alcanzar tal rango. El arzobispado de Toledo, por tanto, será el encargado de encauzar, en lo religioso, los destinos de Orán y Mazalquivir, en contra de los deseos de

por el marqués de los Vélez, gobernador entre 1666 y 1672 , en el mismo emplazamiento que había ocupado hasta entonces la sinagoga de los judíos de Orán, expulsados de la plaza en 1669.

7 A(rchivo) G(eneral) de S(imancas). Patronato Real, Jubileos y Gracias, leg. 27-89. Bula de León X, Roma, 8 enero 1515. León X concedió en esta fecha una bula mediante la cual se otorgaban indulgencias y perdones, incluso de pecados cuya absolución estaba reservada al Pontífice, para todos aquellos que visitaran y dieran limosnas para su mantenimiento.

8 F. JIMÉNEZ DE GREGorio, La visita a Orán ..., p. 946. La iglesia de San Miguel de Mazalquivir depende como aneja de la Iglesia mayor de Orán, siendo Orán y Mazalquivir una sola parroquia.

9 M. NIETo Cumplodo, Fuentes documentales españotas para la historia de Argelia: Archives Nationales (Argel), Actes du Seminaire International sur les sources espagnoles de l'historie algérienne, $\mathrm{n}^{\circ}$ spécial 10-11 (1984), p. 134.

10 Así se recoge en el anónimo memorial que, bajo el título MEDIO para defender las costas de Africa, assegurando las plaças que el Rey nuestro Señor tiene en ellas, ilustrando las ordenes militares, de que su Magestad es Maestre y perpetwo administrador. (B(iblioteca) N(acional) de M(adrid), Varios Especiales. 13-21, s.i., s.l., s.a.,), se presenta a Felipe IV en el inicio de su reinado. El autor expone la posibilidad de elevar la ciudad de Orán a la categoría de obispado, con competencias sobre una hipotética diócesis que ocuparía todas las plazas españolas en el norte de África :"No falta quien haya pensado que estaria muy bien que fuese Oran Obispado y el Prior del Convento Obispo, y los freyles canonigos, y esto se dispussiese dandole por territorio y diocesis sefralada los puertos de aquella vanda, y que esto importaria mucho, y demas de otros efetos temporales en lo espiritual, combendria para la administracion de los Sacramentos, culto divino y religion de los moradores de aquellas partes" (cap. IV, fol. 11 r.). La propuesta, sin embargo, no sería observada como conveniente por la Corona, circunstancia por la cual Orán siguí dependiendo en lo religioso de la archidiócesis toledana. 
Fernando el Católico, quien, al menos en teoría, consigue para la Corona el derecho de patronato sobre la iglesia oranesa".

Por lo que respecta a la dirección de la Iglesia en este doble presidio, hay que señalar que la máxima autoridad religiosa es el vicario, representante directo del arzobispo de Toledo en estas plazas norteafricanas controladas por España. Por el papel que está llamado a desempeñar, semejante al del gobernador y capitán general en las vertientes civil, militar y judicial, el vicario debía reunir unas cualidades muy específicas, entre las que se encuentran las de ser "noble y por lo menos Christiano viejo por aver de estar entre tantos infieles, muy christiano y caritativo, piadoso y afable, para tratar muy de veras de su conversión"12. Por lo general, el cargo de vicario va unido al de capellán mayor de las plazas, hecho que, para algunos, es poco aconsejable por la confusión a que puede dar lugar la integración de funciones y cometidos en una sola persona, mientras que para otros es muy beneficioso, por ser "ocasion de tener alli sugeto de importancia"'3. El vicario se sitúa al frente de la Iglesia mayor de Orán, ayudándole en su cometido varios capellanes. Desde este templo, el vicario realiza su labor en pro del mantenimiento de la fe cristiana en las plazas "administrando los sacramentos, celebrando los divinos offiçios y reformando los vizios y pecados publicos con mucho cuydado y diligençia" 14 , ganándose el apoyo y colaboración de las autoridades seculares, así como del conjunto de los feligreses.

También el clero regular tiene una importante representación en Orán y Mazalquivir. Mendicantes y redentores tomaron en sus manos las riendas de una tarea tan compleja como era la que el cristianismo debía desempeñar en estas tierras rodeadas de infieles, y para la que el propio Cisneros había llegado a exponer la necesidad de una estrecha colaboración por parte de las Órdenes Militares, a partir de la confluencia en sus integrantes de aquellas virtudes que se necesitaban para extender la Iglesia a unos enclaves de estas caracterís-

I1 G. SANCHEZ DONCEL, Op. cit., p. 449. El autor afirma que "Cisneros aseguró a la archidióccsis toledana las nucvas tierras conquistadas en tomo a Orán, a pesar de las intrigas de Fernando el Católico por independizarlas del arzobispado toledano". Esta polémica habría que relacionarla con la que protagoniza el enfrentamiento entre la Corona y la iglesia toledana a causa de los fondos con los que se sufraga la empresa conquistadora de Orán.

12 F. JIMÉNEZ DE GREgoRjo, "Relación de Orân" por el vicario don Pedro Cantero Vaca (I631-1636): Hispania, tomo XXII, n 85 (1962), p. 115.

13 Ibidem, p. 90.

14 Es el caso del licenciado Pedro Rodríguez, provisor y vicario de Orán y Mazalquivir, quien, en 1601 , tras veinte años sirviendo primero oficio de capellán y luego de vicario, y alegando estos méritos pide, a sus 70 años, que los 40.000 maravedís de sueldo que tenía los pueda gozar en Cartagena (AGS. G(uerra) A(ntigua), leg. 579, s(in) f(oliar) / 26 septiembre 1601. Consulta deI Consejo de Guerra). 
ticas ${ }^{15}$. Fracasado este propósito, serán franciscanos, dominicos y mercedarios quienes se ocupen de mantener viva la fe cristiana en el doble presidio, tanto en lo referente a la población civil como militar de las mismas. Ahora bien, ello no impidió que religiosos pertenecientes a otras órdenes se acercaran en determinados momentos a las plazas, con el propósito de ofrecer su ayuda y colaboración con respecto a las múltiples y complejas tareas que la Iglesia debía desempeñar en este doble presidio. Éste será el caso de la Compañía de Jesús, presente en Orán y Mazalquivir en los años 1594-95 -dentro del período que comprende nuestro estudio-, de la misma forma que también actuó esta orden en otras plazas españolas de allende el Estrecho, caso de Ceuta y Melilla ${ }^{16}$.

\section{LA DIFÍCIL ACTUACIÓN DE LA IGLESIA EN EL DOBLE PRESIDIO}

El papel que desempeña la Iglesia en Orán y Mazalquivir durante las décadas de los años 80 y 90 del siglo XVI, debe ser valorado atendiendo a sus diferentes niveles de actuación, así como a los condicionantes socioeconómicos bajo los cuales realiza su actividad. Para ello, es preciso conocer hasta qué punto llega a determinar la vida de estos enclaves el hecho de configurarse como puntas de avance del mundo cristiano en medio de territorios dominados por una cultura y una religión diferentes. Junto a ello, la propia circunstancia de que estas plazas aglutinen en su interior confesiones de diversa naturaleza y entidad, será aún más determinante en la actuación de la Iglesia en estas latitudes.

Como Iglesia en sí misma debía, en primer lugar, mantener viva la fe de los cristianos que se habían trasladado para habitar en estas tierras norteafricanas, teniendo especial consideración hacia la guamición allí destacada y sus familiares, protagonistas de las más dramáticas situaciones en las plazas, por la precariedad de condiciones en las que se desarrolla su vida en ellas. En este sentido, los capellanes se ocupan de oficiar misa en los días de precepto en la capilla que cada castillo tiene, y de ofrecer la comunión, además de administrar otros sacramentos tales como la confesión o la unción de enfermos. Para la

15 G. Sánchez Doncel afirma que a pesar de que la propuesta de Cisneros fue bien vista por el rey Católico, el proyecto que éste "quiso realizar en 1512, poniendo en Orán la dicha Orden de Santiago, en Bugía la de Alcántara y la de Calatrava en Trípoli, nunca llegó a realizarse". (G. SÁNCHEZ DONCEl, Op. cit., p. 586); aunque el autor cstima posible la aparición de la Orden de Santiago en Orán, en ningún caso se trataría de una presencia continuada ni estable, ni durante este período final del XVI ni en la primera mitad del XVI, periodos en los que la documentación consultada no ofrece ni un solo indicio del establecimiento de esta orden militar en Orán. Así, en el MEDIO para defender las costas de Africa ..., su autor volverá a insistir a Felipe IV en la necesidad de llevar la Orden de Santiago a Orán, por las beneficiosas consecuencias religiosas y económicas que de ello se derivarían.

16 Agradezco la referencia de estos datos al Dr. D. Bernard Vincent. 
población militar y sus familias, ésta es la única manera posible de sentir cercanos los principios y preceptos de la religión que profesan, dadas las especiales condiciones de vida de las guarniciones en los castillos. Con respecto a la población civil, la Iglesia oranesa intenta que la vivencia y práctica de la fe cristiana sea lo más próxima posible a lo que lo sería en cualquier otro enclave de la España filipina, dando cabida tanto a celebraciones de Semana Santa, como a procesiones del Corpus Christi y a cualquier otra manifestación de la vida religiosa que contribuya a mantener álgido el espíritu cristiano de la población de las plazas.

De igual manera, por tratarse de una Iglesia establecida en territorios dominados por el Islam, y con una evidente presencia de la fe hebraica, se vio obligada a ejercer una relevante labor catequizadora tendente a lograr la conversión de los infieles, tanto se tratase de musulmanes como de judíos. Pero la precariedad de medios con que la Iglesia contaba para llevar a buen puerto esta misión, así como la inexistencia de un programa definido para realizar esta actividad condicionaron en buena medida el resultado de esta empresa. El vicario Cantero afirmará, ya para el siglo XVII, que " (...) de los moros libres se convierten algunos de la ciudad y de la Berbería que son dóciles y más fáciles de convertir que los judíos, la causa que dan ellos es de que discurren y el moro no"17. Estas palabras parecen coincidir con las noticias que, para medio siglo antes, ofrecía Diego Suárez, gente de obras desde su llegada a las plazas en 1577 y soldado en Orán desde 1581 hasta 1604, analista fundamental de las mismas en este período postrero del Quinientos quien, refiriéndose a las dificultades para lograr la conversión de los judíos oraneses, indica que,

"(...) muchas veces han hecho burla los judíos de Orán de nuestro nombre cristiano: do hemos visto a muchos, con esta voz volverse cristianos, salirse de la Judería, entrándose en los monasterios y casas de cristianos, en son y voz de catecúmenos, tratando y andando solamente con cristianos, oyendo los divinos oficjos de misa y sermones, mostrando en todo gran cristiandad, y al cabo de la jornada, cuando ya entendiamos se habían de baptizar, se volvían a su judería de pertinacia y cansada ley, haciendo mofas del nombre cristiano, cosa que nos parece digna de ejemplar castigo: sólo vimos en tiempo de treinta años, que fueron los de nuestra milicia en aquellas plazas, baptizarse dos judíos, la una mujer a la cual la gente de guerra dimos cuatro reales cada uno de limosna para su dote y casamiento; y al judio, que era hijo de Cansino, lengua de Orán (...)"18.

Pero, a pesar de lo indicado por Cantero, tampoco debió ser importante la cifra de musulmanes que renegaron de su fe para convertirse al cristianismo.

17 F. JIMÉNEZ DE GREGORJO, "Relación de Orán"..., p. 111.

18 D. SUÁREZ MONTANÉ́S, Op. cit., parte I, cap. XII, p. 187.

Aficiones y devociones en el antiguo régimen

Hispania Sacra 50 (1998) 
Escasas fueron las conversiones entre los capturados en las cabalgadas, aunque siempre más frecuentes cuando se trataba de niños, y en el caso de moros libres, aunque las conversiones aumentan, tampoco lo hacen en una proporción notable. En uno y otro caso, además, solía tratarse de abjuraciones poco sinceras, alentadas por el miedo y el deseo de mejorar una situación precaria, y escasamente favorecidas por una labor catequizadora gravemente condicionada desde el momento que los religiosos apenas sabían pronunciar alguna palabra en lengua árabe. Fernand Braudel señala con rotundidad la inexistencia de una política de conversión en masa semejante a la que se aplicó a los musulmanes en la Península, afirmando que 'il n'y eut jamais d'effort sérieux de la part des Espagnols pour attirer l'indigene a la foi du Christ" '" . A esta causa habría que añadir la escasa atracción que la conversión podía llegar a suscitar para los musulmanes esclavos, puesto que su adoctrinamiento y posterior bautismo en la fe cristiana tampoco conseguiría devolverles la libertad, siéndoles negado, asimismo, el rescate por parte de las tribus musulmanas a las que habían pertenecido. La exigüidad de estas conversiones musulmanas llegaría hasta el punto de que, cuando el bautismo era solicitado voluntariamente, se hacía necesario elevar una consulta a más altas dignidades eclesiásticas que las que se hallaban presentes en el doble presidio; así ocurre cuando, en 1592, ante el deseo de convertirse al cristianismo de ocho jovenes musulmanes, "cuatro mochachos y cuatro mochachas que quieren ser cristianos y no ir con sus padres"20, el gobernador de las plazas, D. Diego Fernández de Córdoba, se ve en la necesidad de pedirle al vicario, "que lo consulte con el obispo", hecho que parece demostrar la inexistencia de un mecanismo lo suficientemente practicado como para no tener que recurrir a dicha consulta.

Completando las tareas propias del mantenimiento de la fe cristiana y de la labor catequizadora respecto a musulmanes y judíos, la Iglesia oranesa hubo de hacer frente a la necesidad de dar cobijo y rescatar a aquéllos que se vieron perseguidos por causa de su fe en Cristo. En este sentido, habría que citar especialmente a la Orden de la Merced, que realizó una misión fundamental para el rescate de los cristianos cautivos en diversas ciudades berberiscas convertidas desde tiempos anteriores en centros de reclusión para los cristianos capturados, caso de Argel, fundamentalmente, pero también de otras como Túnez o Trípoli, desde el momento en que ambas dejan de formar parte de la zona de expansión española en el norte de África ${ }^{21}$. En contacto con otros miembros

19 F. BRAUDEL, Les Espagnols et l'Afrique du nord de 1492 à 1577: Revue Africaine, $\mathrm{n}^{\circ} 69$ (1928), p. 378.

20 AGS. GA, Leg. 353, fol. $7 / 1$ junio 1592.

21 Recordemos que Túnez cae definitivamente en poder otomano en 1574, tan sólo un año después de la precaria conquista española llevada a cabo por tropas dirigidas por D. Juan de Austria, mientras que Trípoli, que había permanecido en manos de los caballeros de San Juan desde que les 
pertenecientes a la misma orden que se trasladaban desde España a estos enclaves de cautividad, los mercedarios de Orán consiguieron salvoconductos de las autoridades de las urbes berberiscas con los cuales pudieron sacar de los baños a algunos cristianos recluidos en ellos, y llevarlos a Orán. Desde alí embarcarían hacia España, si bien estos rescates vía Orán ni estuvieron perfectamente establecidos por el gobierno de la Monarquía ni por las autoridades eclesiásticas, ni fueron siempre bien vistos desde dentro del doble presidio, por los peligros que de ellos se pudieran desprender para la integridad del control español de las plazas. La gran proximidad entre Orán y Argel facilitaba los contactos con las autoridades de la ciudad musulmana, como da cuenta a Felipe II el comendador de la Orden, Baltasar García, en 1593:

\footnotetext{
"que por su orden se rescataron los cautivos de oran y otros que tienen seguro y salvoconducto del rey de Argel y de los arraez y geniceros tiene neçesidad por si se ofreçiese yr a argel. Supplica a V.M. pues es serviçio de dios darle liçencia para quando se ofreçiere qque en ello reçevira merçed"22.
}

En tanto en cuanto pudiera ser población de Orán y Mazalquivir la que estuviera cautiva en Argel, la presencia de los mercedarios en la ciudad berberisca tendería a acentuarse. Pero, por lo general, no siempre les era posible a estos religiosos salir de unas plazas donde su presencia era tan necesaria, con el objeto de acudir a estas redenciones. Además, el riesgo que corrían al salir de ellas era el mismo que el que sufría el resto de la población que traspasaba sus murallas: no será raro asistir a la cautividad en Argel de miembros de las órdenes religiosas que desempeñaban su labor en Orán y Mazalquivir. En 1589, se da cuenta de cómo fray Pedro Díaz, sacerdote y predicador dominico, Juan Conejero Dorado y fray Pedro de Godoy, vicario en el convento mercedario de Orán, están cautivos en Argel, donde son maltratados ${ }^{23}$. La conjunción de to-

fuera cedido por Carlos V en 1530, se había perdido ya en 1551. La orden de la Merced, junto con la de la Trinidad, cjercería el papel fundamental en lo relativo al rescate de cautivos cristianos en Berbería. Sobre este tema, es de gran interés el estudio realizado por E.G. FRIEDMAN, Spanish captives in North Africa in the Early Modern Age (16c-I8c), Madison, 1983, donde, además de estudiarse en profundidad la cuestión de la cautividad, se analiza la labor de las Órdenes redentoras y el procedimiento a través del cual se llevaba a cabo el rescate de cautivos en Berbería.

22 AGS. GA, leg. 390, fol. 147/ 30 junio 1593. Memorial de fray Baltasar García, comendador de la Orden de la Merced.

${ }_{23}$ AGS. GA, leg. 269, fol. 78 / 28 enero 1589. Carta en nombre de fray Pedro Díaz a Felipe Il solicitando una real cédula "para que el general y oficiales de V.M. de las dichas plazas le hagan plicgo y credito de las mandas y limosnas que la gente de guerra y fabricas de la dicha oran y mazarquivir le quisieren hazer de lo que V.M. les deve para ayuda a su rescate", y AGS. GA, leg. 270, fols. 17-18 / junio 1589. Carta en nombre de fray Pedro Díaz, Juan Conejero Dorado y fray Pedro de Godoy, a Felipe II.

Aficiones y devociones en el antiguo régimen

Hispania Sacra 50 (1998) 
das estas dificultades supondrá una importante merma en la puesta en práctica de esta labor redentora que compete a la Iglesia del doble presidio, careciendo de la eficacia y magnitud que dicha tarea pudiera tener, dada la proximidad de estas plazas a Argel.

Todas estas funciones que la Iglesia debe desempeñar en Orán y Mazalquivir -mantenimiento de la fe cristiana, labor evangelizadora respecto a musul manes y judíos y redención de cautivos - se ven significativamente condicionadas por las circunstancias socioeconómicas presentes en las plazas en este período final del reinado de Felipe II. Es cierto que, en estos años, la Iglesia se mantiene firme, continuando con la realización de aquellas labores que estuvieron en sus manos desde el mismo momento en que se hizo realidad el restablecimiento del cristianismo en los nuevos territorios norteafricanos conquistados para España. Pero si hay algún rasgo que pueda caracterizar la realización de dichas actividades durante este período, no cabe duda de que sería la existencia de relevantes precariedades y limitaciones, también constatadas -aunque en otras esferas de influencia-, para la población militar del doble presidio. Los diferentes memoriales escritos tanto por el vicario como por los superiores de cada una de las tres órdenes religiosas presentes en estos territorios, así como por el gobernador y otros mandos militares de las plazas, atestiguan cómo la escasez de personal religioso y la falta de recursos económicos fueron los problemas principales a los que la Iglesia de Orán y Mazalquivir debió hacer frente en este período.

La necesidad de un mayor número de personas pertenecientes al estamento eclesiástico viene constatada por las peticiones que, año tras año, se hacen desde el interior de ambas plazas con vistas a conseguir el envío desde la Península de capellanes que permitan acercar la celebración de los oficios religiosos a la guarnición cristiana que sirve en el doble presidio. Juan de Acosta, alcaide del castillo de Rosalcázar, deja constancia en el año 1589, de la necesidad de que sea enviado un capellán para que oficie las misas de los domingos y festivos, petición que recoge el gobernador, D. Diego Fernández de Córdoba, un año más tarde, haciéndola extensiva a otros castillos del presidio ${ }^{24}$. En 1594, es el capellán Pedro Rodríguez, luego vicario de Orán, quien hace constar que la iglesia de Mazalquivir se halla sin cura por fallecimiento del que desempeñaba el cargo ${ }^{25}$.

24 AGS. GA, leg. 272, fol. $273 / 13$ diciembre 1589, y AGS. GA, leg. 282, fol. $332 / 24$ febrero 1590.

25 AGS. GA, leg. 407, fol. 20/ 4 noviembre 1594. Según los datos de G. SÁNCHEZ DONCEL, Op. cit., p. 572, Pedro Rodriguez fuc nombrado vicario de Orán el 7-4-1597, pero en la documentación consultada en aparece ya en 1595 con el título de vicario, y hasta entonces, con el de capellán. (Sobre sus áltimos años en Orán y Mazalquivir, vid. Supra, nota 14).

Aficiones y devociones en cl antiguo régímen Hispania Sacra $50(1998)$ 
Tanto las autoridades religiosas como civiles de estas plazas denunciaron con frecuencia los perjuicios que podían desprenderse de la falta de un número adecuado de personas pertenecientes al estamento eclesiástico. Todos ellos pusieron de manifiesto la dimensión que cobraba el problema en una tierra donde el cristianismo convivía con otras confesiones religiosas y en la que no sólo había que hacer frente a las necesidades espirituales de la población cristiana, sino también llevar a cabo la doble labor rescatadora y evangelizadora a la que se veía encauzada por estar en tierra de infieles. Precisamente, este desfase entre el número de religiosos allí existente en estos años y el que hubiera sido necesario para realizar la triple labor que la Iglesia de Orán y Mazalquivir tenía encomendada, viene a confirmar el hecho de que su actuación no fue, en la práctica, todo lo completa ni constante que en teoría sí hubiera deseado ser.

Pero si la solución de este primer problema no exa en exceso compleja, centrándose en el envío a estos territorios de un mayor número de representantes de la Iglesia desde una España en la que éstos son ciertamente cuantiosos en esta época, lo referente a las dificultades económicas no presentaba una solución tan sencilla. Y es que hay que tener en cuenta que, dejando a un lado los sueldos de vicario y capellanes, la Iglesia de ambas plazas se sustentaba básicamente de limosnas, tanto de las que entregaba la gente de guerra del doble presidio como de las que enviaba la propia Corona. La cuantía de las primeras variaba en relación con las pagas que se hacían efectivas a la guamición, las cuales eran muy exiguas, y además, cobradas con alarmantes retrasos. A pesar de ello, estas limosnas alcanzaban en ocasiones cantidades relevantes, pues los religiosos de Orán y Mazalquivir las citan como destacada aportación en determinados casos, como es el de los mercedarios en la edificación de la casa de la Orden en dicha ciudad ${ }^{26}$.

Las limosnas reales, por su parte, eran entregadas anualmente y solía tratarse de cantidades fijas, bastante reducidas casi siempre, en contra de lo que pudiera suponerse. En 1593, la limosna concedida por la Corona para el sustento del convento de dominicos de Orán era de 30.000 maravedís ${ }^{27}$ - es decir, tan sólo 80 ducados-, cantidad que, en 1594 también fue permitida por Felipe II para hacer efectiva al convento de Nuestra Señora de la Merced ${ }^{28}$. Tan sólo un año después, aparece fechada la carta en la que Felipe II pide al goberna-

26 AGS. GA, leg. 337, fol. 134 / 6 mayo 1591. Una vez que el convento ha sido construido gracias la las limosnas reales y a las de la gente de guerra, el prior de la orden pide a Felipe Il se le conceda licencias de saca de grano para, con lo obtenido, poder adquirir diversos ornamentos para la iglesia del convento. Las limosnas concedidas por la gente de guerra a este convento de la Merced seguitán siendo relevantes, alcanzando en 1603 la considerable cantidad de 1.325 .032 maravedís (AGS. GA, leg. 608, s.f. / 29 junio 1603).

27 AGS. GA, leg. 390, fol. 280/1593.

28 AGS. GA, leg. 398, fol. $296 / 19$ febrero 1594. 
dor, D. Gabriel Niño de Zúñiga, información detallada sobre el monasterio de San Francisco, desde donde Roque Martínez, guardián del dicho convento, le ha hecho relación de la extrema pobreza en que viven los doce sacerdotes que componen el total de esta orden religiosa en Orán, haciendo presente la necesidad de que se les concedan también a ellos los 30.000 maravedís anuales de limosnas reales que ya reciben dominicos y mercedarios. El gobernador contesta señalando que la necesidad de los franciscanos es cierta, ya que apenas reciben limosnas por ser la gente de guerra tan pobre ${ }^{29}$. Comenta cómo estos frailes acuden a los castillos de Rosalcázar y San Gregorio a oficiar las misas, además de confesar a la guarnición cada día y, de forma muy reveladora, Niño añade que los franciscanos son bien vistos por los soldados por estar siempre al tanto de sus necesidades espirituales, aunque lo cierto es que, tanto franciscanos, como mercedarios y dominicos, fueron aceptados sin reservas por parte de la población cristiana del Oranesado. En relación con esto, conviene subrayar que la labor desempeñada por cada una de las órdenes religiosas en estos territorios ha de ser entendida como complemento fundamental de la que realizan las demás. Pero, si bien es cierto que no es posible hablar de rivalidades en el terreno religioso propiamente dicho, no ocurre lo mismo con lo relativo al terreno económico: el hecho de que las tres órdenes pidan la equiparación en las limosnas reales que reciben, obedece a su deseo de no quedarse atrás respecto de los favores dispensados por la Corona, y aunque todas ellas se unen para hacer patente a Felipe II su extrema penuria ${ }^{30}$, no toleran que haya intromisiones en los beneficios económicos que algunas de ellas tienen asegurados desde tiempos anteriores. Así to hace constar el prior del convento de Santo Domingo el Real en 1597:

"Los Reies chatolicos que fundaron este convento de Santo Domingo el Real le hizieron de merced la limosna de cinco mill bulas para sus meparos y sustento de los Religiosos y en tiempos pasados por no contradezir este convento que no llego a su notiçia se dividio la dicha limosna, en la yglesia maior y san francisco por terceras partes despues no se por que ocasion se le dio el quinto al convento de la merced y a llegado a mi notiçia que el comendador de la merced pretende entrar en iguales partes. suplico a V.alteza no aia lugar su petiçion que es en agravio deste convento por ser pobre y estar con grandísima neçesidad de labrar"31.

29 AGS. GA, leg. 440, fol. $212 / 18$ junio 1595. Carta de D. Gabriel Niño de Zúniiga, gobemador interino de Orán y Mazalquivir, al Consejo de Guerra.

30 AGS. GA, leg. 296, fols. 225-226 / febrero 1590. Las tres ordenes se unen para hacer presente a la Cotona la máxima penuria que atraviesan debido a una subsistencia basada en las limosnas de la gente de guerra y las donaciones hechas a través de los testamentos de la población de Orăn.

31 AGS. GA, leg. 492, fol. 168 / 24 diciembre 1597. Carta del prior de la orden de Santo Domingo a Felipe II. 
La penuria y escasez a la que continuamente, durante estas décadas finales del Quinientos, hacen referencia las diferentes órdenes religiosas establecidas en Orán y Mazalquivir, afecta tanto al sustento de los propios religiosos, como a la construcción y reforma de los edificios en los que éstos habitan y realizan su labor. Dichos centros aún no se hallaban totalmente finalizados en los años postreros del siglo XVI, a pesar de que la restauración de la Iglesia en ambas plazas se remontaba a varias décadas atrás. Ante la necesidad de finalizar estas construcciones, las órdenes religiosas se verán obligadas a pedir a la Corona alguna otra forma de financiación que complementase a unas limosnas reales que ni siquiera eran suficientes para el sustento de los clérigos. De ahí que en este período final del Quinientos se hagan muy frecuentes las peticiones a la Corona, por parte de la Iglesia de Orán, de licencias de saca de grano -obtenido principalmente a través de las entregas y ventas realizadas por los moros de paz-, negocio al que habían recurrido no sólo buena parte de los comerciantes y mercaderes de la ciudad, sino incluso los mismos gobernadores, alentados por las importantes sumas de dinero que, mediante la venta del grano a ciudades o particulares de España, se llegaba a conseguir ${ }^{32}$. Así, por ejemplo, aparecen los mercedarios en 1589 , pidiendo al rey un licencia de saca de mil fanegas de trigo para acabar de edificar su convento en Orán ${ }^{33}$, mientras que dos años después indican que, habiendo conseguido finalmente levantar la casa de su congregación gracias a la limosna de la gente de guerra y a la enviada por la Corona, necesitan otras dos licencias de saca —una de trigo y otra de cebada- para realizar la ornamentación de la iglesia ${ }^{34}$. En 1596 , por mediación de Baltasar García, comendador de dicha Orden, se hace relación de las estancias que tenía este convento, señalando que constaba de "quatro quartos altos y vaxos, un refretorio y dies çeldas y coçina y otros aposentos para el serviçio deste convento con un guerto en medio de los dichos claustros"35. La existen-

32 Sin embargo, no siempre que era necesario proceder a la terminación de un determinado edificio se recurría a la petición de una licencia de saca; en otras ocasiones se pedía directamente a la real Hacienda una cierta cantidad de dinero, caso, por ejemplo, de los dominicos, cuando han de acabar de construir la capilla mayor de su iglesia en 1590 (AGS. GA, leg. 298, fol. 63/25 junio 1590. Consulta del Consejo de Guerra favorable a la concesión de mil ducados para terminar de construir la capilla mayor y vivienda de los religiosos del convento de Santo Domingo de Orán), o cuando en 1598 piden una libranza en rentas reales para poder reedificar su convento (AGS. GA, leg. 533, fol. 78 / 14 octubre 1598. Carta del prior de la orden de Santo Domingo al Consejo de Guerra).

33 AGS. GA, leg. 267, fol. 186 / 20 septiembre 1589. Carta de fray Rodrigo de Viena, procurador general de la Orden de Nuestra Señora de la Merced, al Consejo de Guerra.

34 AGS. GA, leg. 337, fol. 134 / 6 mayo 1591. Consulta del Consejo de Guerra sobre el convento de Nuestra Señora de la Merced.

35 AGS. GA, leg. 456, fol. 84 / junio 1596. Carta de fray Baltasar García, comendador de la orden de la Merced de Orán, al Consejo de Guerra. En relación con el huerto que cita el documento, $M$.

Aficiones y devociones en el antiguo régimen

Hispania Sacra 50 (1998) 
cia de diez celdas nos hace pensar en la cortedad del número de mercedarios afincados en Orán en este período, al tiempo que, relacionándolo con la cifra anteriormente señalada de doce franciscanos, confirma la idea de la insuficiencia de clero regular en ambas plazas en relación con el total de población cristiana del doble presidio, teniendo en cuenta que sólo la guarnición alcanzaba en esta fecha - 1596 - el total de 1.368 personas $^{36}$.

La cuestión de la construcción de edificios religiosos no sólo atañe a las tres órdenes, sino también a la propia Iglesia mayor que, en 1594, aún no se hallaba totalmente terminada. Ello no se debía tanto a un proyecto arquitectónico de grandes dimensiones ${ }^{37}$, sino más bien a los problemas económicos, así como de personal y de material a los que la principal iglesia de Orán había tenido que hacer frente desde que, tras la conquista, se decidiera edificarla en el mismo emplazamiento donde hasta entonces había estado enclavada una mezquita. En 1594 se cuantifica que se llevan gastados en la construcción de la misma un total de 8.300 ducados, siendo necesario emplear otro tanto para poder acabar$\mathrm{la}^{38}$. Igualmente, ante la falta de envíos de madera para la realización de las bóvedas, se ha pedido a Pedro de Fermoselle, mayordomo de artillería, la entrega de ciertas cantidades de este material que no pueden ser devueltas ni pagadas en su justa medida ${ }^{39}$. La necesidad de acabarla es muy grande, ya que,

"por estar en frontera y a vista de moros y judios y que de aver parado el edifiçio della toman ocassion a deçir contra nuestra santa relission y fee catolica demas que para la decençia y reverençia con que se deve administrar y çelebrar el culto divino, y offiçios y para que la gente y soldados de la dicha çiudad puedan caver y estar en ella con la devoçion que se rrequiere y conviene y es muy necesario que se acave el edifiçio y obra de la dicha yglesia, y por ser pobre de fabrica y to que hasta agora se ha gastado a sido de limosnas y obras pias que los veçinos y soldados difuntos an hecho"40.

Por esta razón, se acaba pidiendo una licencia de saca de trigo de 4.000 fanegas en relación con la cosecha del año siguiente; pero, en 1595, el vicario

de Epalza, J.B. Vllar, Op. cit., p. 134, afirman que los conventos de estas plazas poseían "unos diminutos jardines interiores, verdaderos oasis de verdor en el entramado urbano de Orán".

36 AGS. GA, leg. 456, fol. 86 / 24 junio 1596. Relación de gente de guerra de Orán y Mazalquivir.

37 Según el plano 223 contenido en la citada obra de M. Epalza y J.B. Vilar, la iglesia mayor de Orán constaba de una sola nave con crucero y capillas laterales, no llegando a 40 metros de longitud. Ello demuestra que no fueron sus dimensiones las que provocaron la tardanza de su definitiva edificación, sino más bien la falta de fondos para terminarla con celeridad.

38 AGS. GA, leg. 411, fol. 100/ 23 abril 1594. Consulta del Consejo de Guerra.

39 AGS. GA, leg. 415, fols. 353-4/ marzo 1594. Informe de Juan de Castafieda, veedor y Diego de Arce, contador de Orán y Mazalquivir.

40 AGS, GA, leg. 417, fol. 76/1594. Carta de la Iglesia de Orán al Consejo de Guerra.

Afjciones y devociones en el antiguo régimen Hispania Sacra 50 (1998) 
Pedro Rodríguez, ante la imposibilidad de realizar esta saca con el trigo de Orán, se vería obligado a pedir permiso para realizarla con el trigo siciliano ${ }^{41}$. Aun a pesar de la insistencia del vicario con vistas a arbitrar medios para conseguir el dinero y material necesario para acabar la Iglesia mayor de Orán, lo cierto es que ésta aún tardaría bastante tiempo en ser finalizada por completo. Así lo atestigua el vicario Cantero de Vaca, cuando en su Relación, indica que, -todavía en los años 30 del siglo XVII-, era una iglesia "de una nave, muy buena y clara, toda de cantería, y su bóveda, aunque está cubierta, no lo está de cargar. Obra de que necesita mucho y costará poco y será bien encargarla a los vicarios para que poco a poco la vayan acabando"42.

La suma de todas las aportaciones indicadas hasta el momento que eran percibidas por la Iglesia de Orán - limosnas de la gente de guerra y de la Corona, licencias de saca y libranzas en rentas reales-, no eran suficientes para sufragar tan numerosos gastos como los contraidos por el estamento eclesiástico de Orán en relación con el mantenimiento de los religiosos, construcción de conventos e iglesias y realización de sus actividades pastorales, evangelizadoras y redentoras. De ahí que la totalidad de los componentes de la Iglesia de Orán y Mazalquivir, dejando atrás las posibles rencillas entre órdenes religiosas, decidieran unirse -en 1592 - para pedir a Felipe II la concesión de una parte del botín obtenido por los soldados en las jornadas y cabalgadas. Ello no era, en absoluto, una idea totalmente novedosa, sino que, como ellos mismos argumentaban, había sido tradición en este lugar, estando soldados y capitanes generales de acuerdo con esta pretensión, a pesar de no señalarse nada al respecto en la ordenación sobre el repartimiento de los botines de cabalgadas que Felipe II realizara en $1565^{43}$. El problema surge en relación con el duque de Cardona, a la sazón gobernador de Orán y Mazalquivir, quien se negaba a conceder una parte del botín a la Iglesia, especificando que sólo podían participar en el reparto quienes intervinieran en las cabalgadas. La respuesta de dominicos, franciscanos y mercedarios es muy significativa:

41 AGS. GA, leg. 438, fol. 262 / 29 septiembre 1595. Consulta del Consejo de Guerra. El Consejo propone que lo conmute en $\mathbf{5 0 0}$ salmas francas de Sicilia, aprobándolo posteriormente Felipe II.

42 F. JIMÉNEZ DE GREGORIO, Op. cit., p. 85.

43 Esta ordenación es realizada previa petición de D. Hemán Tello, gobemador de las plazas en esta fecha, ante la inexistencia de una regulación especifica al respecto. Según D. Suárez "este caballero (D. Hemán Tello) reformó grandemente las órdenes de milicia de aquellas plazas; en que asimismo informó y pidió a Su Magestad mandase hacer, en cristiandad y justicia, la orden de repartimiento de las presas en cabalgadas que por tierra y mar se hiciesen, que hasta allí se habían quedado los generales pasados con ellas, contra toda razón y justicia" (D. SUÁREZ MONTAÑÉs, $O_{p}$, cit., parte I, cap. VII, pp. 124-125). Un traslado de este ordenamiento puede consultarse en AGS. GA, leg. 283 , fols. 334-336/ 1565 .

Aficiones y devociones en el antiguo régimen Hispania Sacra 50 (1998) 
"Y no es de creer que quiera V.M. seamos nosotros comprehensivos en el orden que V.M. tiene dado diçiendo que al que no asistiere no se de parte (que es la causa por donde el duque nos excluye). Pues a los saçerdotes no se nos permite pelear sino rezar, que son las armas de la yglessia con las quales haçemos çentinela en estas plazas. quanto mas que siempre estamos prestos y alistados para acompañar a la gente que sale a semejantes ocasiones y servir en todo lo que toca a nuestro officio siendo mandados del general que aqui asiste"44.

El hecho de que las órdenes estuvieran dispuestas a participar en las jornadas, si ése era el único medio a partir del cual podían entrar en el reparto del botín, indica hasta qué punto el clero regular se hallaba en una situación económica crítica. De cualquier forma, lo único que se estaba defendiendo era el derecho de la Iglesia a perpetuar una prerrogativa de la que había disfrutado durante mucho tiempo en estas plazas y de la que ahora necesitaba más que nunca.

A pesar de las dificultades a las que ha de hacer frente la Iglesia del Oranesado en los últimas décadas del reinado de Felipe II, se puede afirmar que sigue realizando con plena dedicación e interés aquellas funciones que tenía encomendadas, sobre todo en lo relativo al mantenimiento de la fe cristiana en un territorio donde los españoles vivían rodeados de otras confesiones. No deja de estar muy presente la idea de que en Orán hay bastantes judíos y algunos musulmanes -esclavos principalmente- además de los que viven a pocas leguas de las plazas y de los que entran en ellas de vez en cuando para realizar su comercio o para entregar al gobernador los productos acordados en virtud del seguro fírmado con él en nombre del rey de España. Frente a los riesgos que de ello pueden derivarse, es preciso oponer un culto cristiano sólido, asentado en un estamento eclesiástico lo suficientemente numeroso, y con iglesias, capillas y conventos ya edificados en su totalidad, tal y como deja entrever Lorenzo Vidal, prior de la Orden dominica, quien, al manifestar la necesidad de reedificar el convento de la orden, indica que "esta a vista de judios y moros que se rien de ver semejantes casas arruinadas y no favorecidas por ser ellos tan puntuales en el falso culto de sus sin[ag]ogas y mezquitas"45.

44 AGS. GA, leg. 367, fol. 162 / 1592. Carta de fray Alonso Vaillo, fray Juan Lozano y fray Baltasar García, representantes de cada una de las tres ordenes religiosas presentes en Oran y Mazalquivir, al Consejo de Guerra.

45 AGS. GA, leg. 492, fol. $168 / 24$ diciembre 1598. 


\section{INQUISICIÓN EN ORÁN Y MAZALQUIVIR: LA DEFENSA DE LA FE CRISTIANA EN TERRITORIO DE FRONTERA}

Desde su establecimiento en España, por bula de Sixto IV en 1478, la Suprema y General Inquisición había funcionado a partir de un Consejo central bajo el cual actuaban diversos tribunales repartidos por toda la geografía española, extendiendo su jurisdicción a aquellas tierras que progresivamente se habían ido incorporando a la Monarquía en estos años finales del siglo XV y primeras décadas del XVI. En el caso del doble presidio norteafricano objeto de nuestro estudio, se advierte la presencia -en un primer momento- de un tribunal de la Inquisición en Orán, cuya aparición aún no se ha podido datar con exactitud, barajándose las fechas de 1509 y $1516^{46}$. En cualquier caso, lo cierto es que, en 1525, Orán pierde la capacidad de gestionar su propio tribunal del Santo Oficio y, a partir de ese momento, el control y la vigilancia preestablecidos para mantener la ortodoxia cristiana en estas plazas pasa a ser desempeñado por un tribunal de la Península. En concreto, será el de Murcia, creado en 1488, el que por razones de proximidad y de gran facilidad de comunicación marítima con el doble presidio, se encargaría desde entonces de resolver los asuntos que supusieran un ataque al estricto mantenimiento de la fe cristiana en este doble presidio ${ }^{47}$, independientemente de que algún caso de especial relevancia o gravedad pudiera ser tramitado por el tribunal de Toledo, dada la autoridad religiosa del arzobispo toledano sobre ambas plazas.

Como el resto de los tribunales del Santo Oficio, el de Murcia estaba compuesto, además de otros cargos de menor relevancia, por dos o tres inquisidores, un fiscal, notarios, calificadores, varios secretarios y algunos teólogos, así como por varios familiares, siendo el representante principal de la Inquisición

46 J. BLÁZQUEZ MIGUEL, El tribunal de la Inquisición de Murcia. Murcia, 1986, p. 12, nota 8. El autor afirma que la mayor parte del archivo de la Inquisición de Murcia se ha perdido, como consecuencia de los agentes externos (polilla y humedad), y de la actuación del propio Consejo, que procedí a quemar en el año 1800 todos los papeles de los siglos XVI y XVII por considerarlos inservibles. Por esta causa, los investigadores sólo disponemos de las relaciones de causas —además de algunas cartas-, enviadas a Madrid, para conocer la actuación del tribunal murciano. Para la localización de dichas relaciones, vid. del mismo autor, Catálogo de los procesos inquisisoriales del Santo Oficio de Murcia: Murgetana, LXXIV, (1987), pp. 5-109.

47 Desde la conquista de estas dos plazas norteafricanas, serán Málaga y Cartagena los puertos de España que, dada su mayor proximidad a estas latitudes del continente vecino, canalizarán los contactos entre la Península y ellas. Hasta la década de los años $\mathbf{8 0}$ del siglo XVI, el puerto de Málaga ejerce el papel primordial en esta comunicación España-Orán. La inexistencia de un tribunal inquisitorial propio hasta 1526, fecha de creación del de Granada, que engloba también bajo su jurisdicción a Málaga y Almería, impidió que, al desaparecer el tribunal de la Inquisición de Orán en 1525, estos territorios norteafricanos pudieran colocarse bajo la jurisdicción del de Granada, aún inexistente, debiendo recurrir al de Murcia, que ya habia sido creado en 1488.

Aficiones y devociones en el antiguo régimen

Hispania Sacta 50 (1998) 
en el doble presidio el propio vicario quien, además de todas sus funciones como delegado del arzobispo de Toledo y máximo responsable de la Iglesia, desempeñaba el cargo de comisario del Santo Oficio. Como tal comisario, su misión era la de recibir denuncias y recabar pruebas contra los inculpados, mediante la audición de testigos, remitiéndolas posteriormente a los inquisidores, quienes habrían de decidir al respecto de cada caso.

El método de actuación del Santo Oficio en este doble presidio no solía diferir del habitual. Cualquier persona que considerase que había actuado al margen de la ortodoxia cristiana podía presentarse por voluntad propia ante el vicario, actitud infrecuente que, sin embargo solía acentuarse con motivo de la concesión de algún edicto de gracia, al asegurar éstos mayor benevolencia en el trato inquisitorial. Más usual era acudir por obligación, tras haber sido denunciado por alguien en el plazo establecido por un edicto de fe. Tras la primera confesión ante el vicario, en su calidad de comisario del Santo Oficio, $o$ ante alguna otra personalidad autorizada, caso de los priores de los conventos presentes en las plazas, el reo es remitido al tribunal de Murcia, donde realiza una segunda declaración, pasando después a la cárcel secreta, donde es encerrado hasta que su proceso se resuelva. A tenor de los casos estudiados en relación con Orán y Mazalquivir para las últimas décadas del reinado de Felipe II, cabe señalar que la tradicional imagen de la Inquisición como brazo ejecutor de castigos siempre crueles y rigurosos, imagen ya discutida desde hace varias décadas por la historiografía ${ }^{48}$, se muestra también improcedente en lo que se refiere a estas plazas. En efecto, el tribunal de Murcia sólo se mostró incompasible en situaciones muy concretas, comprobándose cómo, incluso en el caso de aquellos reos que, habiendo confesado su yerro, no se retractaban de él, éstos eran condenados a penas que podian incluir desde la confiscación de bienes y los azotes, al destierro y, a lo sumo, la cárcel perpetua y la temible condena a galeras. Ésta última, cuando se trata de períodos más prolongados, se convierte en verdadera condena a una muerte lenta, pero segura. En ninguno de los casos consultados, a pesar de la gravedad de alguno de ellos, aparece sentencia de relajación propiamente dicha, siendo más frecuente la tendencia a absolver al reo, en cuanto no esté claro que haya incurrido en delito. No en vano, la misión del Santo Oficio de Murcia en este sentido, era facilitar el regreso a la más ortodoxa fe cristiana de los que se habían apartado de ella. Por esta razón, el Consejo de la Inquisición proclamó numerosos edictos de gracia

48 Obras como la de H. KAMEN, La Inquisición española, Barcelona, 1979, J. PÉREZ V1LLANUEVA (dir.) La Inquisición española. Nueva visión, nuevos horizontes, Madrid, 1980, B. BENNASSAR, Inquisición española: poder político y control social, Barcelona, 1981, o la más reciente de J. BLÁZZUEZ MIGUEL, La Inquisición, Madrid, 1987, abren el camino a la necesidad de matizar la valoración de la actuación inquisitorial. 
en los que aseguraba la absolución a todos aquellos renegados que confesaran por voluntad 49 .

La tipología de los casos que se remiten al tribunal murciano en estas décadas finales del Quinientos es amplia y variada, aunque, dadas las circunstancias que rodean a unos territorios como Orán y Mazalquivir, presidios cristianos en tierras musulmanas, los delitos de islamismo serán, lógicamente, los más numerosos. Pero, de igual forma, encontramos personas juzgadas por judaizar, blasfemar, practicar la bigamia, e incluso, por incurrir en el delito de solicitación.

\section{Islamizantes}

Dentro de esta categoría se hace necesario distinguir dos grupos claramente diferenciados. Por una parte, estaría la población militar del doble presidio que, agobiada por las precariedades de la vida diaria decide desertar del ejército y pasar a tierra musulmana, renegando del cristianismo y aceptando la fe del Islam ${ }^{50}$. Por otra parte, se encontraría la población civil de las plazas, en la que el grupo mayoritario de islamizantes estaría constituido por los musulmanes que se acogen a la fe cristiana para, más tarde, renegar de ella por una u otra circunstancia, si bien incluso los propios cristianos habitantes del doble presidio incurren en este delito por causas varias, siempre muy significativas de las condiciones de vida que se hallan presentes en estos enclaves.

En lo que se refiere a la población militar de las plazas, el caso más frecuente que recogen las relaciones de causas del tribunal de la Santa Inquisición de Murcia es el relativo a aquellos integrantes de la guarnición que, abando-

49 B. y L. Bennassar establecen la concesión de Edictos de Gracia por parte del Santo Oficio de Murcia, previa orden del inquisidor general en los años 1579-1584, 1592 y 1594, para el período que abarca el presente estudio. (B.y L. BENNASSAR, Los cristianos de Alá. La fascinante aventura de los renegados, Madrid, 1989, pp. 282-283). Por lo general, los edictos de gracia que se conceden a la población de Orán y Mazalquivir en estos años van destinados a renegados que abandonan su fe para convertirse al Islam, temporalmente al menos. Tienen dos años de duración y cuando están próximos a finalizar, son los propios inquisidores de Murcia los que lo avisan al Inquisidor General, por si está de acuerdo en proceder a su renovación.

so Recordemos que estos soldados deben hacer frente a labores de vigilancia, protección y defensa de unos enclaves continuamente arnenazados por tierra y por mar. Frente a ello, los salarios que reciben son exiguos, casi siempre llegan con varios años de retraso y no se entregan completos. De ellos se descuentan los gastos de vestimenta, armas y alimentación, y eso en el caso de que desde España se envíen las remesas necesarias, que tampoco suele ser lo más usual. En estas condiciones, la vida del soldado en Orán y Mazalquivir se acaba convirtiendo en una lucha continua contra el hambre y la desnudez y en pro de que se le hagan efectivos los pagos que se le adeudan, y todo ello enmarcado en una actividad continua en las tres facetas indicadas más arriba, que, en ocasiones incluso, fuerza a prolongar durante la noche el trabajo desarrollado durante todo el día.

Aficiones y devociones en el antiguo régimen

Hispania Sacra 50 (1998) 
nando el doble presidio cristiano, se adentran en las tierras musulmanas de Berbería con el propósito de encontrar a través de ellas una vía de salida del norte de África y una posibilidad de regreso a España. Para entender esta circunstancia, hay que tener en cuenta la gran dificultad que la gente de guerra encontraba a la hora de serle concedido un permiso mediante el cual poder regresar termporal o definitivamente a España. Detrás de esto lo que aparece no es sino el problema de reclutamiento existente en la España del siglo XVI, especialmente en lo que respecta a levas destinadas a los presidios norteafricanos ${ }^{51}$.

Cuando el soldado que ha sido enviado a servir a la Corona en Orán o en Mazalquivir comprueba la imposibilidad de regresar a España mediante la concesión de un permiso por parte del gobernador y capitán general, la huida se articula como principal baza para poder salir del presidio. Lo más eficaz, aun dentro de las grandes dificultades que conlleva, es intentar la fuga por mar. $Y$ es que, aun a pesar de que ser descubierto intentando embarcar clandestinamente en una galera es causa de condena a muerte, adentrarse en un Mediterráneo plagado de corsarios y piratas turco-berberiscos, es contemplado como opción más favorable que intemarse en unos territorios magrebíes dominados por el Islam ${ }^{52}$. Mientras que en el primer caso, el riesgo puede terminar felizmente, con el regreso a España, en el segundo, si no se desea ir directamente a tierras del Islam y renegar, habrá que empezar por sortear todos los embates de las tribus musulmanas enemigas para, en el mejor de los casos, llegar a otro presidio cristiano, donde se comprobará que las condiciones de vida son similares a las de Orán y Mazalquivir. Y vuelta a empezar. Pero lo

51 En este sentido, la fluida comunicación entre la Península y el norte de África jugará un papel contrario a los intereses defensivos de la Monarquía. Las noticias sobre la penuria en la que vive la gente de guerra de los territorios del otro lado del Estrecho llegan con facilidad a España, y la respuesta de estos hombres que deciden enrolarse en tareas castrenses es contundente: no les importará el destino al que sean enviados, siempre que no se trate de los presidios norteafricanos. Ante esta actitud, la Corona se verá en la necesidad de arbitrar nuevas formas mediante las cuales poder seguir llevando a estas plazas la gente de guerra necesaria para defenderlas, recurriendo incluso al engarto. Buen ejemplo de ello es el propio Diego Suárez Montañés, quien embarca en Cartagena en 1577 creyendo que su futuro tendrá como escenario Italia, cuando, en realidad, es Orán el punto de destino del navío en que viaja. ( A., BeRBRUGGER, Mers-El-Kebir et Oran de 1509 à 1608 d'après Diego Suarez Montañes: Revue Africaine, vol. 9, (1865), p. 113).

52 Así, cuando llegan a Orán o a Mazalquivir galeras procedentes de España que traen bastimentos para la guarnición, algunos de estos soldados aprovechan para esconderse en ellas, y asegurar de esta manera su regreso a la Península, aun a riesgo de su propia vida. Y es que intentar la huida por mar implica entrar en contacto con el patrón de la embarcación, o con intermediarios de dicho navío, así como burlar la severa vigilancia existente en el camino hasta el punto de la costa donde está la barca que llevará a dicho navío. En el peor de los casos, tendrá que hacer frente la necesidad de acudir a nado hasta dicho lugar, amén de estar alerta para sortear a los propios musulmanes, al acecho para capturar a cuanto cristiano saliera de los confines del doble presidio, y llevarlo a Argel, como destino prioritario, para pedir después una fuerte cantidad por su rescate. 
preferible no es siempre lo más viable, por lo que se hará necesario articular otras vías de actuación, que incluyen la opción de entrar en tierras musulmanas y no precisamente en dirección a otros presidios cristianos Así, Francisco Montero, soldado de Orán pero natural de Madrid, desea regresar a su España natal, y estima como única formula posible intentar la huida del presidio. Se pone de acuerdo con otros soldados que están en su misma situación para embarcarse con dirección a España. Pero, temiendo ser descubierto y sufrir el duro castigo que le impondría el gobernador y capitán general, como máxima autoridad militar de las plazas, juzga ser mejor opción el internarse en Berbería, lo que hace, llegando a renegar de su fe cristiana para así iniciar una nueva vida en el Islam. Finalmente escapa, y regresa a Orán. Acogerse a edicto de gracia y reconocer los errores cometidos, le hace ser absuelto por el Santo Oficio de Murcia ${ }^{53}$. Otros soldados, por el contrario, desechan desde el principio la posibilidad de intentar la huida por mar: Antón Ruiz, cordobés, soldado en Orán durante ocho años, acaba internándose en Berbería después de esperar durante largo tiempo una licencia de salida que nunca llega. Huye a Mostaganem, a 14 leguas de Orán, donde reniega. Aprovechando la concesión del mismo edicto de gracia, acude por voluntad ante las autoridades del Santo Oficio, y tras reconocer su comportamiento, y asegurar que en su corazón nunca dejó de ser cristiano, es absuelto y tan sólo se le imponen ciertas penitencias espirituales ${ }^{54}$. También es posible encontrar situaciones mixtas, en las que una primera fuga a Berbería, es continuada por una huida a través del mar: Luis Marín, morisco granadino, estando como soldado en Orán, pasa a Argel con otro compañero, harto de soportar las difíciles condiciones de vida de la guarnición del presidio. Allí se convierte al Islam, "yendo a la mezquita y haziendo los demas ritos y ceremonias", pero su objetivo es volver a España y regresar al cristianismo. Para conseguirlo, se hace a la mar como corsario, siendo su nave capturada por dos galeras españolas, de las que, tras pasar un tiempo como fuerza de remo, acabará escapando y llegando a Murcia ${ }^{55}$. Estaríamos aquí ante un ejemplo muy común: el del cristiano renegado que, asegurándose así un salario y una manutención, participa del corso argelino que tanto auge alcanza tras el final del gran enfrentamiento en el Mediterráneo entre Cristiandad e Islam, después de la batalla de Lepanto y la firma de las primeras treguas hispano-turcas. Desde este punto de vista, Argel se consolida como punto de destino para estos soldados desertores, mientras que Tremecén y Mostaganem son casi siempre simples etapas de la huida hacia esta ciudad; Argel es "el polo de

${ }^{53}$ A(rchivo) H(istórico) N(acional). Inq(uisición), leg. 2022 / 14, fol. 13 v. / af́o 1584. Relaciones de causas del Santo Oficio de Murcia. Absuelto ad cautelam, penitencias espirituales.

54 AHN, Inq., leg. 2022 / 14, fol. 15 r. / año 1584. Absuelto ad cautelam, penitencias espirituales.

55 AHN, Inq., leg. 2022/23, fol. 22 v. año 1594. Admitido a reconciliación.

Aficiones y devociones en el antiguo régimen

Hispania Sacra 50 (1998) 
atracción, la ciudad que captaba a los europeos y los integraba bien en el cuerpo de jenízaros, bien en la flora corsaria, o incluso en los dos a la vez"56.

Ahora bien, no todos los casos de guarnición que deserta y huye de Orán nos remiten a situaciones de fuga voluntaria $o$, al menos, es una voluntad que se intenta ocultar por razones obvias en las declaraciones ante el Santo Oficio. La propia idiosincrasia de estos presidios, enclavados en medio de territorios dominados por el Islam, provoca la existencia de circunstancias específicas que acaban por integrar en el mundo musulmán a soldados que quizás no tuvieran predeterminación de abandonar su servicio a la Corona. Juan García, labrador, vecino de Tendilla, sirve como soldado en Orán durante nueve años. En el transcurso de una cabalgada contra moros de guerra, se queda dormido, siendo capturado y llevado a Mostaganem, donde reniega, como única solución a lo que de otra forma se hubiera convertido en una forma de vida aún más dramática que la que ha debido sufrir en el presidio, al perder incluso su libertad. Pero, en verdad, él mantiene sus antiguas creencias cristianas, lo que le lleva a intentar huir a Orán. Fracasada su tentativa, es llevado a Argel, desde donde organizará, esta vez con éxito, una nueva huida hacia Orán ${ }^{57}$. En otras ocasiones, no hay que emplear la fuerza para conseguir llevar a un soldado cristiano a tierra del Islam; también se puede recurrir al engaño para lograr el mismo fin: Alonso Ruiz Torroba, es un soldado de Orán desterrado --por una causa de una pendencia que no se refiere en su expediente- a la Torre de los Santos, uno de los enclaves defensivos del doble presidio, situado en las proximidades del camino que comunica Orán con Mazalquivir y, por tanto, fuera de las murallas de Orán. Allí es engañado por una mora amiga, que le hace pasar a Tremecén, a dieciocho leguas al oeste de Orán, donde reniega ${ }^{58}$.

En el fondo, a lo que asistimos una y otra vez no es sino a la expresión de una misma constante, integrada en un escenario de enfrentamiento entre dos religiones y dos culturas bien diferenciadas, que se disputan el control de las costas del Magreb central desde comienzos de siglo. El deseo de un amplio sector de la guarnición de este doble presidio de abanđonar su misión, dadas las precariedades a las que tiene que hacer frente cada día, queda enmarcado en un ámbito puntual y específico, en el que más allá de una muralla y de los castillos que componen el perímetro defensivo de la plaza, todo lo que se encuentra es Islam. Y la única forma de subsistir en ese mundo, sin caer en las mismas penurias que han padecido en el doble presidio, es por medio de la

56 L. y B. BENNASSAR, Los cristianos de Ala ..., pp. 277-278.

57 AHN. Inq., leg. $2002 / 14$, fol. 14 v. / Año 1584. Acogido a edicto de gracia, Absuelto ad cautelam, penitencias espirituales.

58 AHN. Inq., leg. 2022 / 14, fol. 14 r.-v. / Año 1584. Acogido a edicto de gracia Absuelto ad cautelam, penitencias espirituales. 
abjuración de la fe cristiana y de la conversión al Islam ${ }^{59}$. Pero, en último término, son mayoría los soldados que acuden a este tipo de comportamientos como paso intermedio, quizás necesario, para acabar regresando a España, de donde salieron un día y de donde muchos de ellos nunca hubieran marchado de saber que iban a ser enviados a servir a un presidio norteafricano. Cuando pasa el tiempo y comprueban que no por haber renegado y por vivir como y entre musulmanes tienen más posibilidades de embarcarse hacia España, acabarán por preferir regresar al presidio del que huyeron, arriesgándose aún más que cuando salieron de él para intemarse en la Berbería ${ }^{60}$. Aprovechando los edictos de gracia hechos públicos por el Santo Oficio de Murcia - precisamente para recuperar este tipo de renegados-, expiarán sus culpas y se volverán a integrar en la Iglesia, beneficiándose de la tendencia, por parte de los gobernadores de las plazas, de no castigar a estos soldados desertores que retornan a Orán o a Mazalquivir, como fórmula para que otros que han hecho lo mismo regresen sin temer posibles sanciones ${ }^{61}$.

Pero, también provocado por el continuo contacto entre Cristianismo e Islam, asistiremos a situaciones donde el militar que reniega, no lo hace precisamente por culpa de las precarias condiciones de vida a las que se ve sometido, o al menos, no sólo por eso. En este sentido, se comprueba cómo las permanentes relaciones entre ambas religiones acaban dando como resultado la aparición de casos en los que un cristiano estima que la fe verdadera no es la suya, sino la musulmana. En 1572, Sebastián Bermúdez, gastador en Orán, recibe una de las condenas más rigurosas de entre todas las que encontramos

59 También hay quien declara ante el Santo Oficio que su intención fue preferir la condición de cautivo, manteniendo la adhesión a la fe de Cristo, antes que renegar y convertirse al Islam. Sea cierta esta pretensión o sea sólo un intento de desagraviar su comportamiento ante las autoridades inquisitoriales, lo cierto es que también éstos acaban convirtiéndose al Islam una vez que llegan al destino de su cautiverio; es el caso, por ejemplo, de Antonio de Mendoza, portugués, quien trabajando como cantero en Mazalquivir, -engrosando, por tanto, la categoría de gente de obras y, en consecuencia, también bajo sueldo del rey de España-, desea huir a España en barca. Viendo las dificultades existentes, opta por adentrarse en Berbería, "con el proposito de ser cristiano cautivo y que estando en argel le persuadieron que renegase y lo hizo". (AHN. Inq., leg. $2022 / 14$, fol. 13 v.- 14 r. / Affo 1584. Acogido a edicto de gracia $A$ bsuelto ad cautelam, penitencias espirituales).

60 Ginés Pérez, natural de Orihuela, que había huido a Tremecén en compañía de otros soldados de Orán, tras haber sido adoctrinado en el Islam en Argel, regresa a Tremecén donde casa y tiene una hija, y desde no dudará en concertarse con otro cristiano para regresar a Orán "con achaque de que salian a una cabalgada". (AHN. Inq., leg. $2022 / 22$, fol. 12 r.-v. / Año 1592). Acogido a edicto de gracia Absuelto ad cautelam, penitencias espirituales). Cit. por L. y B. BENNASSAR, Los cristianos de Alá ..., p. 271.

61 En el fondo, las autoridades del doble presidio conseguian un importante beneficio con el regreso de estos desertores arrepentidos: la obtención de noticias sobre sistemas de fortificación, defensa y acontecimientos puntuales que están teniendo lugar en ciudades como Argel. Tremecén o Mostaganem, en las que estos soldados han entrado y permanecido durante un cierto período de tiempo.

Aficiones y devociones en el antiguo régimen

Hispania Sacra 50 (1998) 
en relación con estos renegados. Se le acusa de haberse concertado con otro a irse a tierra de moros para vivir como turcos "siguiendo la seta de mahoma teniendola por buena y creyendo que en ella se salvaria" 62 . No aduce, en ningún momento, haber actuado así por culpa de la precariedad de su vida como integrante de la guamición, sino que, a pesar de saber los problemas que puede tener, no duda en confesar su sincera adhesión al Islam. Aun siendo sometido a tormento, Bermúdez se ratifica en su afirmación ante el Santo Oficio de Murcia, lo que le supondrá una condena especialmente grave: además de confiscación de bienes y cien azotes, deberá servir cinco años como remero de galera, lo que equivalía a una auténtica pena de muerte a medio plazo. A la Corona le servía en gran medida un condenado a galeras, al contribuir durante un tiempo a mantener activa la flota española, siendo muy frecuente, en especial a partir de la batalla de Lepanto (1571), que las penas de relajación fueran conmutadas por ésta.

Como contrapunto de estas situaciones protagonizadas por la guarnición de las plazas, hemos de señalar aquéllas en las que es la población civil la que incurre en delitos de islamismo. También aquí se advierte la existencia de casos de abjuración del cristianismo por aparente convicción de que la doctrina de Alá es la fe verdadera. Ello vuelve a ponernos en la pista de la gran influencia que ejerce el permanente contacto entre estas dos religiones en los individuos pertenecientes a una y otra religión, independientemente de que lo que al final decida a cada uno abjurar de su fe sea la necesidad de huir de una situación vital insufrible, o un auténtico proceso de cambio en materia de fe. Fernando de Castro, hortelano estante en Orán, Juan Rodríguez, residente en dicha ciudad, y Miguel Jiménez, residente en Mazalquivir, ven resueltos sus procesos por el Santo Oficio de Murcia en 1572, ante el que han sido denunciados por haber intentado todos ellos - por separado- huir a tierra de moros. La relación no deja constancia de la verdadera causa de esta actuación, pero los tres, aun negando la intención y recibiendo tormento sobre la misma, acaban siendo condenados a abjurar de vehementi, además de a penas que oscilan entre el servicio en galeras, la cárcel perpetua, $o$ ambas más azotes ${ }^{63}$.

Pero no siempre la conversión al Islam, por parte de estos cristianos "civiles", es la consecuencia de una determinación previa; en ocasiones, se llega a la abjuración del cristianismo de forma fortuita, sin que haya existido una auténtica voluntad de abandonar este credo. La frágil barrera que separa ambas religiones puede llegar a ser traspasada a causa de los más increíbles azares. Así le ocurre a Lucas Brocal, vecino de Cartagena, quien estando en Orán, donde

62 AHN. Inq., leg. 2022 / 6, fol. 1 v. / Año 1572.

63 AHN, Inq., leg. 2022 / 6, fols. 2 v.- 4 r. / Año 1572. En el caso de Fernando de Castro, el reo tiene ya dos procesos asimilados por la Inquisición de Granada, al ser natural de Baza; uno por delito de protestantismo, y otro por concertar irse a tierra de moros a renegar con moriscos, ofreciéndoles armas. 
tenía un molino arrendado, procede a vender diez fanegas de trigo para ser sacadas a España, con lo que desobedece un bando del capitán general y gobernador del doble presidio que prohibe sacar trigo de las plazas hasta que no sea hecha la provisión de la gente de guerra. Temiendo ser prendido por tal actuación, no le queda más remedio que huir de las plazas cristianas, y adentrarse en Berbería, aunque según declara, con intención de regresar a España en cuanto pueda. Su peripecia en tierra musulmana le lleva a renegar, aunque en su corazón, continuó siendo cristiano ${ }^{64}$.

Este tipo de peripecias se demuestran aún menos marginales en el caso de los cristianos nuevos de moros que residen en el doble presidio de Orán y Mazalquivir durante el período que analizamos. En su gran mayoría se trata de esclavos bautizados --tras un deficitario proceso de instrucción en la fe cristiana- que, por una u otra circunstancia, acaban volviendo a tierras musulmanas, reconvirtiéndose al Islam. El hecho de haber quedado en el norte de África tras recibir el bautismo, en vez de ser enviados a la Península, unido a que no alcanzan la libertad a través de la conversión, les hace verse tentados por la posibilidad de volver con sus familiares musulmanes, los cuales, en muchas ocasiones además, pertenecían a tribus de moros de paz que tenían permiso para entrar y salir de Orán en situaciones determinadas, lo que hacía más fácil el contacto con los bautizados, e incrementaba el deseo de éstos de salir del doble presidio.

La razón última por la que estos esclavos acaban saliendo del doble presidio o, al menos, la que aducen en sus declaraciones ante el tribunal del Santo Oficio de Murcia, puede obedecer a muy diversos condicionantes, pero todas ellas mantienen el común denominador de una sociedad en la que Islam y Cristiandad están más próximos de lo que en teoría pudiera parecer. Luisa, berberisca, esclava de Juan Alemán, vecino de Orán, fue hecha cautiva, "baptizada y enseñada en las cosas de nuestra fee", pero años más tarde volvió a tierra de moros, de la que no salió hasta que fue de nuevo capturada y llevada a Orán. Aduce que la causa de su marcha del presidio fue el engaño por parte de un soldado "que se fue a rrenegar y que como muger que sabia poco se fue con el". A pesar de haber readoptado todos los usos y costumbres propios del Islam, Luisa afirma no haberse apartado nunca realmente de la fe de Cristo, alegrándose cuando fue hecha cautiva por segunda vez ${ }^{65}$. Algo semejante le sucede a Francisco de Frías, natural de Berbería, que recibe el nombre de su amo al ser bautizado y que se presenta voluntariamente ante el vicario de Orán para

64 AHN. Inq., leg. 2022/17, fols. 16 v.-17 r. / Affo 1586. Acogido a edicto de gracia. Absuelto ad cautelam. Cit. por L. y B. BENNASSAR, Los cristianos de Ala ..., p. 273.

65 AHN. Inq., leg. 2022 / 8, fol. 7 r-8 v. / Año 1579. Misa en una parnoquia, abjuración de vehementi, penitencias espirituales, prohibicion de salir de estos reinos.

Aficiones y devociones en el antiguo régimen

Hisparia Sacra 50 (1998) 
confesar que "le sonsacaron un soldado de la dicha çiudad berberisco aunque christiano y otro moro y le inçitaron para que todos fuesen a berberia diçiendole que pues era de casta de moros y tenia alla sus padres y parientes se fuese alla"66. La instigación a quien, por su origen musulmán, se considera próximo a la posibilidad de renegar de su bautismo cristiano es el argumento empleado por este esclavo para expiar sus culpas ante el Santo Oficio, pero obsérvese cómo los incitadores son, precisamente, mogataces ${ }^{67}$, en los que se personifica con claridad la fácil transgresión de la frágil frontera entre Islam y Cristiandad en estas latitudes norteafricanas.

Igualmente encontramos casos en los que es el mal trato otorgado por los amos lo que obliga a estos esclavos convertidos al cristianismo a volver a tietra de moros, donde se les hace recuperar la fe en el Islam ${ }^{68}$. Cuando estos malos tratos se combinan con el deseo del esclavo de alcanzar la libertad, las posibilidades de que acabe huyendo a Berbería se multiplican considerablemente. Entre estos esclavos, además, circula el rumor de que, si consiguen estar entre moros durante un año y un día, sus amos pierden sus derechos sobre ellos, quedando libres de nuevo. Alonso, esclavo de Juan González, vecino de Orán, fue hecho cautivo a los doce años, siendo bautizado en la iglesia de Mazalquivir al cabo de tres años de instrucción en el cristianismo. Pero, en cuanto unos primos suyos, moros de paz, entran en Orán, le convencen para que regrese con ellos a Berbería, porque "le havian dicho que si se bolviese a su natural y alla estava año y dia alcançava libertad y ansi agora avia venido de su voluntad", según aduce en una primera confesión, de la que se desdice después. De la misma manera, empezará afirmando no saber que estaba bautizado y no querer ser cristiano, para después indicar que sí quiere serlo y que lo anterior lo dijo por miedo. En su proceso, también se discute si volvió a Orán por su propia voluntad, o por resultado del negocio hecho por su amo con otro moro, por el cual, si éste conseguía traer a su esclavo, les daría a ambos diez doblas ${ }^{69}$. Son todos ellos testimonios fehacientes de una situación específica,

66 AHN, Inq., leg. 2022 / 25, fol. 14 r.- v. Año 1596. Acogido a edicto de gracia, absuelto ad cautelam, penitencias espirituales.

67 Vid. supra, nota 2.

68 Es el caso, por ejemplo de Juan Jorge, que fue hecho cautivo a los cinco o seis años, siendo llevado a Orán, donde es bautizado. AHN. Inq., Ieg., 2022/14, fol. 14 v.- 15 r. / Año 1584. Acogido a edicto de gracia, absuelto ad cautelam, penitencias espirituales.

69 AHN, Inq., leg. 2022 / 13, fols. 20 r.- 21 r. / Año 1583. Una misa, abjuración de vehementi, penitencias espirituales. El proceso, abierto en 1579 , se prolonga de forma bien significativa, hasta 1583. Las diferentes versiones que se dan en cada confesión, obligan a examinar más de una a los testigos. Así, en 1581, con motivo de la visita del inquisidor de Murcia al doble presidio, éste da cuenta de que aprovecharía su estancia en Orán para tomar nueva declaracion a los testigos, en una fecha en la que Alonso ya es esclavo de otro amo y está en Cartagena (AHN. Inq., leg. 2800, s. f. I año 1581. Otro buen ejemplo de la importancia concedida por estos esclavos convertidos al deseo de 
propia de territorios en los que los contactos entre ambas confesiones son continuos y generan situaciones en las que nada es definitivo en sí mismo.

Ahora bien, no todos los cristianos nuevos de moros entran en la categoría de esclavos. Hay un reducido grupo de personas que son libres, y que, sin embargo, también son procesadas por delitos de islamismo. En ellos, obviamente, no caben las razones aducidas por los esclavos en relación con el deseo de alcanzar la libertad, pero sí que es factible observar también los problemas derivados de la precaria labor de catequización que se lleva a cabo sobre estos musulmanes que entran en las plazas cristianas, así como la tentación que supone vivir permanentemente en contacto con el "otro lado" de la frontera. Leonor de Borja, mujer de Miguel de Cabra, soldado de Orán, es acusada de haber opinado en alta voz que "el diablo la avia metido por las puertas de Oran a volverse cristiana", así como por no querer ir a misa, no confesarse, evocar a Fátima y a Mahoma, y vitupetar a los cristianos diciendo que lo son sólo "de campanilla". Leonor deberá abjurar de vehementi, no salir de Orán durante los próximos ocho años y, muy significativamente, se da orden de "que acabe de ser ynstruyda en nuestra santa fe catolica"70.

Para completar este panorama, es necesario recordar que también todos estos eventos pueden ser contemplados desde la perspectiva contraria, es decir, de igual forma que para todos los casos señalados hasta ahora es el Islam el que, al menos a priori, se configura como mundo deseado, hay situaciones en las que el paso a dar es precisamente el contrario. Aquí se encuadrarían todos aquellos cristianos que, desde su condición de cautivos en enclaves musulmanes, ante los malos tratos que sufren por parte de sus amos, acaban renegando, pero mantienen viva su fe cristiana en el corazón. Muchos de ellos dirigen a Orán sus huidas de tierra musulmana, con lo que este presidio se configuraría como un símbolo de la acogida cristiana a quienes se habían visto obligados a vivir entre infieles o, incluso, a renegar de su fe, si bien, hasta entrado el siglo XVII, no se puede hablar de un mecanismo establecido de redención de cautivos a través de Orán ${ }^{71}$. Juan Bautista Navarro, cautivo desde los once años en

\footnotetext{
conseguir su libertad es el del berberisco Francisco de Navarrete, quien, sirviendo al ejército cristiano como mogataz, se queda - durante una cabalgada-- en Tremecén, "no con deseo de ser moro sino por conseguir libertad porque avia oydo decir que estando alla entre moros un año y un dia quedava libre" (AHN, Inq., leg. 2022/14, fol. 15 r. / 1584, Acogido a edicto de gracia, absuelto ad cautelam, penitencias espirituales).

70 AHN. Inq., leg. 2022 / 17, fols. 3 r- 4 r. / Afro 1586.

"Hacia 1626, la práctica de las redenciones a través de Orán para cautivos cristianos es Argel ya está perfectamente establecida. Un musulmán de Argel irá a Orán a concertar los rescates, quedando en prenda hasta que éstos se lleven a cabo; mientras un cristiano de Orán hará lo propio en Argel. Una vez decidido por ambas partes quién habrá de rescatarse y a qué precio, los redimidos se embarcarán en Argel por cuenta de las autoridades de Orán, mientras que Argel pone de su parte la custodia
}

Aficiones y devociones en el antiguo régimen

Hispania Sacra 50 (1998) 
La Goleta y luego trasladado a Argel, Blas Fernández, portugués capturado en la batalla de Alcazarquivir, o Antón, corso llevado cautivo a Argel a los cinco años, son sólo algunos de los ejemplos de estos cristianos que ven en Orán la tabla de salvación para su fe, tras haber tenido que pasar un largo tiempo viviendo como adeptos al Islam ${ }^{72}$.

\section{Judaizantes}

La presencia de un núcleo judío en la plaza de Orán ${ }^{73}$ favorecerá la aproximación a los ritos hebreos por parte de los cristianos que viven en el presidio. La existencia de una judería, una sinagoga, de libros y ceremonias hebreas, acercan de forma clara y evidente la fe judía a los habitantes de Orán. En este sentido, aunque muy poco numerosos - al menos en la documentación manejada para las últimas décadas del reinado de Felipe II--, aparecen algunos casos en los que se remiten al tribunal del Santo Oficio de Murcia cristianos residentes en Orán sospechosos de judaizar.

No hallamos en esta categoría una diferenciación concluyente entre civiles y militares; unos y otros pudieron acercarse por igual a la fe judía, puesto que esta aproximación, a diferencia de los que islamizan, no dependía de forma directa de las precariedades que se vivieran en las plazas. Don Diego Sarmiento, natural y veinticuatro de Sevilla, residente en Orán, es juzgado por el tribunal inquisitorial murciano por haber entrado varias veces en la sinagoga, habiendo escuchando oraciones hebreas. Se le denuncia por alabar la fe judía, y por sospechosos conocimientos de la Cábala, que llegan a superar incluso, a los de los propios judíos. Pero, es que, además, este contacto con la minoría hebrea de Orán, ha llegado a convertirse en amistad, pues el reo come y bebe con los judíos. Si a ello se añade que se recela de él porque no va a misa y no confiesa desde hace varios años, todo se coaliga para que sea denunciado a la Inquisición, que inicia un largo proceso contra él ${ }^{74}$. En 1570 ya está abierta la causa, momento en que el mayor problema al que la Inquisición de Murcia debe hacer frente es al hecho de que los principales testigos del caso son judíos

de estas naves - para que no sean atacadas en su travesía a Orán-, así como de los barcos en los que pasa el dinero desde Espaffa al presidio. Sobre este tema, vid., B. Alonso ACERo, Orán y Mazalquivir en la política norfeafricana de Espafta, 1589-1639. Tesis doctoral inédita, Universidad Complutense, Madrid, 1997, pp. 513-520.

72 AHN. Inq., Jeg. $2022 / 14$, fol. 15 v. / Año 1584, y leg. $2022 / 25$, fols. 13 v.- 14 r. Todos ellos se acogen a edicto de gracia, absueltos ad cautelam, penitencias espirituales).

73 Vid. supra, nota 2.

74 AHN. Inq., leg. 2022 / 6, fol, 6 r.- v. / Año 1572. Pena de misa mayor en un día de domingo, abjuración de levi y 100 ducados de multa. 
y, por razones obvias, no se quiere que éstos entren en Murcia, por lo que se plantea hacer este juicio en Orán ${ }^{75}$.

Pero, de igual manera que la existencia de una judería en Orán es contemplada como un gran peligro para el mantenimiento de la ortodoxia cristiana en el doble presidio, para algunos españoles de la Península, la permanencia de un núcleo judio en Orán, cuando esta posibilidad ha sido desechada para los territorios peninsulares desde hace casi un siglo, supone un incentivo que, a los más curiosos, o menos convencidos de su fe cristiana, les acaba por seducir. Diego García, natural de Burgo de Osma, confiesa ante un franciscano de Orán que estando en Baeza tuvo una gran duda sobre si la verdadera era la ley de Cristo o la de los judíos, y decidiéndose por ésta última, "aviendo oydo que en oran avia juderia se determino pasar alla a tornarse judio y bibir con ellos" 76 . Los judíos de Orán le acogen en el seno de su comunidad, le adoctrinan y le entregan un hábito judío. Convertido al judaísmo, Diego García "entendio que avia andado herrado" y confesó por voluntad ante este franciscano, que se ve obligado a denunciar el caso ante el vicario, en su calidad de comisario del Santo Oficio. Para este acusado la pena impuesta será especialmente dura, teniendo en cuenta, como agravante, que no era la primera vez que se apartaba del cristianismo, aunque también es significativo que se contemple como desagravante la testificación por parte de judíos; en total, cinco años de cárcel y cien azotes será la condena que habrá de cumplir el mencionado reo.

Mientras cristianos de dentro y fuera de las plazas muestran sus devaneos con la ley de Moises, los musulmanes que se acercan a las plazas, o que viven en ellas en calidad de esclavos - bien sea continuando con su fe, como catecúmenos o como bautizados--, no presentan ningún caso de acercamiento al judaísmo, a pesar de las estrechas relaciones que musulmanes y judíos mantuvieron en estos enclaves norteafricanos.

\section{Otras tipologías}

Además de los casos de islamizantes, los más numerosos que se denuncian al Santo Oficio durante estas décadas finales del reinado de Felipe II, y de los

75 "(...) los que deponen contra él (D. Sarmiento) son seis testigos los tres judios y los otros cristianos biejos y si huviesen de benir aqui los judios seria grande escandalo y podrian resultar muchos ynconbinientes allende que seria nescesaria cedula particular de Su Magestad (...)", motivo por el cual el inquisidor del tribunal murciano propone que el juicio se celebre en Orán, en el monasterio đe los dominicos o en el de los franciscanos. (AHN. Inq., leg. 2798, s.f. / Afro 1570. Carta de la Inquisición de Murcia al Consejo de la Inquisición)

76 AHN. Inq., leg. 2799, s.f. / Año 1577.

Aficiones y devociones en el antiguo régimen

Hispania Sacra 50 (1998) 
de judaizantes, mas exiguos, cabría señalar algunos otros tipos de delito que son notificados a la Inquisición, y con los que se completa el paisaje de desviaciones de la ortodoxia cristiana que se presentan en el doble presidio de Orán y Mazalquivir durante este período. Todos ellos son casos menores, que la propia Inquisición considera como secundarios, frente a lo que fueron siempre sus intereses prioritarios - la persecución de criptojudíos e islamizantes--., pero también ellos nos hablan de una sociedad en la que, a pesar de las características tan específicas que la categoría de presidio les otorga, se repiten los mismos comportamientos y situaciones que se pueden observar dentro de los límites peninsulares de la España del Quinientos, los cuales afectan tanto a la población civil, como a la militar, y también a las órdenes religiosas presentes en doble presidio.

Por blasfemia, por ejemplo, tiene que responde Domingo Terradas, vecino de Orán, ante el inquisidor de Murcia; haber dicho que dios no tenía hijo, que dios trató con mujer, estar amancebado, y afirmar que tener acceso carnal con mujeres pagándolas por ello no era pecado, son motivos suficientes para acabar siendo reprendido, advertido, obligado a abjurar de levi, y desterrado perpetuamente de Orán y del distrito de la Inquisición de Murcia ${ }^{77}$. Igualmente se perseguirán los delitos de bigamia, aunque en estas últimas décadas del Quinientos la Santa Inquisición haya decidido no detener a los bígamos "más que si se prueba formalmente el primer matrimonio"78, lo que provoca una marginación evidente de esta infracción dentro del conjunto de los delitos tipificados por la Suprema. Fernando Salido, soldado de Orán, entra en esta dinámica, puesto que se comprueba la existencia de un primer matrimonio, en Iznatoraf (Jaén), su ciudad natal. Este enlace, aunque él se esfuerce en negarlo, aun contraido por la fuerza, fue consumado, habiendo nacido un hijo. Al estar viva su primera mujer y haber casado por segunda vez en Orán, será condenado a cinco años de galeras al remo y sin sueldo ${ }^{79}$.

Junto al civil y al soldado, un religioso, fray Diego Navarro, mercedario predicador en el convento de la orden en Orán, es denunciado por tres mujeres por "averlas solicitado en la confesion con palabras y torpes tocamientos para actos torpes y desonestos", lo que obliga a este fraile a tener que responder del delito de solicitación ${ }^{80}$. El asunto se agrava porque como testigos declaran otros frailes de la misma orden que afirman haber oido que el reo trataba carnalmente con ciertas hijas de la confesión. Comprobado que las denunciantes eran mujeres de buena fama y reputación, y aun defendiéndose "diçiendo que

77 AHN. Inq., leg. 2022 / 24, fol. 2 r.-v. / Año 1595.

78 B. BENNASSAR, Inquisición española ..., p. 282.

79 AHN. Inq., leg. 2022 / 23 , fols. 2 v.- 3 r. / Año 1594.

80 AHN. Inq., leg. 2022 / 20, fols. 4 v-5 r. / Año 1588.

Aficiones y devociones en el antiguo régimen Hispania Sacra 50 (1998) 
siempre avia administrado la confesion con mucha Reberençia y Rectitud (si bien) fuera della podria aver tenido algun descuido como hombre", fue mandado recluir en un monasterio de su orden durante un año, pero además, inhabilitado para predicar y confesar hombres y mujeres de por vida, así como desterrado de Orán durante diez años. Esta pena tan rigurosa en un período en el que ya casi todas las condenas por este caso suelen ser leves ${ }^{81}$, bien puede ser interpretada como un deseo - por parte de la jurisdicción inquisitorial-- de dar ejemplo entre un estamento eclesiástico que, por estar realizando su labor en un enclave donde el continuo contacto con judíos y musulmanes puede dar lugar a tantos problemas, tiene que tener un especial cuidado en no incurrir en comportamientos alejados de la estricta ortodoxia de la fe cristiana.

81 "Por regla general, sobre todo desde finales del siglo XVI, las penas impuestas eran muy leves (...). Los casos más graves (...) se saldaban con una privación perpetua -que luego solía reducirse a unos cuantos affos- de confesar a hombres y mujeres y un afio de reclusión en un convento. Algunos casos extremos (...) eran condenados a cinco años de destierto". J. BLÁZQUEZ MIGUEL, La Inquisición,... p. 99.

Aficiones y devociones en el antiguo régimen Hispania Sacra 50 (1998) 